\title{
Habitat selection by cattle along an ephemeral channel
}

\author{
MICHAEL A. SMITH, J. DANIEL RODGERS, JERROLD L. DODD, AND QUENTIN \\ D. SKINNER
}

Authors are associate professor (first 3), and professor, respectively, Range Management Department, University of
Wyoming, Laramie 82071 .

\section{Abstract}

Because of widespread concern about cattle grazing effects on riparian zones of public lands, seasonal habitat selection by cattle was studied along a cold desert area ephemeral waterway of northcentral Wyoming. Little is known of grazing effects on ephemeral streams compared to perennial streams. Cattle activity was monitored in small pastures and a surrounding large allotment in spring, summer, and fall. Observations included activity and habitat where it occurred. Concomitantly, utilization levels, protein content, and dry matter content of forages were determined in the small pastures.

A higher percent of cattle selected channel and floodplain habitats than percent area of habitats while a lower percent of cattle selected upland habitat than percent of this habitat in the area. Utilization levels of forages except greasewood (Sarcobatus vermiculatus (Hook.) Torrey) in the floodplain were not greatly different among habitats. Protein and dry matter content of forages did not vary greatly among habitats, except greasewood had higher protein and lower dry matter than other species and received much higher use. Forage quality declined in summer and fall. Animal preference for channel habitat was attributed to more available forage in the channels. In contrast, selection of floodplains was due to succulence and high protein content of greasewood. Comparison of cattle selectivity between small pastures and the large allotment indicates that greater avoidance of upland areas by cattle is likely due to greater distances to drinking water in the large allotment.

\section{Key Words: seasonal, biomass, utilization, protein, succulence}

Distribution patterns of grazing cattle, reasons for selection of habitats, and differential utilization of forages within habitats provide a basis for grazing management and range improvement planning. Recent emphases on grazing influences on vegetation and channels in riparian zones (Kauffman and Krueger 1984), water quality, and nonpoint pollution have intensified the need to understand these processes. Overgrazing has long been considered to be a cause of ephemeral channel alteration (Bryan 1925). Cattle prefer perennial stream riparian zones over upland range sites (Roath and Krueger 1982). Forage quality and abundance (Pinchak et al. 1991) and water availability (Ames 1978) are important factors leading to selection of riparian habitats.

Information is particularly lacking on grazing in relation to ephemeral channels, the most widespread channel type in cold desert regions. Ephemeral channels cover more area and have less vegetative cover potential than perennial channels. Proper grazing management of ephemeral channels could have greater impact

\footnotetext{
Published as journal article JA 1614 of the Wyoming Agricultural Experiment Station.

This work was supported by Wyoming Department of Environmental Quality, Wyoming Water Research Center, and Bureau of Land Mangement.

Manuscript accepted 30 November 1991 .
}

than management along perennial channels on nonpoint source pollution, specifically sediment yield.

We initiated a study of seasonal habitat selection by cattle in relation to ephemeral channels and forage quality in a cold desert ephemeral watershed in northwestern Wyoming, with concomitant data on forage utilization levels. Habitat selection, forage quality, and forage utilization were determined in small seasonal pastures where distance to water was small and assumed to have a minor influence on grazing distribution. Habitats selected by cattle were also determined in 2 areas of a large allotment where water sources could be up to $6 \mathrm{~km}$ distance away from potential grazing sites and cattle movements were uncontrolled from spring through early fall. Results reported here are part of a study that additionally characterized the dynamics of vegetation and channels in grazed and ungrazed reaches of an ephemeral channel.

We hypothesized that ephemeral riparian zones would be preferred over uplands because of more or higher quality forages. Hypotheses explicitly tested were that proportions of cattle using each of the various habitats present in the areas studied were not the same as the proportions of these habitats in the areas, and that crude protein content, dry matter content, and utilization of forages were not equal across habitats. We also nonstatistically compared selection of habitats between small pastures and the large allotment to determine the extent to which knowledge of small pasture grazing behavior could be generalized to larger areas and to determine the degree that water availability influenced use of upland areas.

\section{Materials and Methods}

\section{Study Area}

The study area is located in the Bighorn Basin of northcentral Wyoming along 15-Mile Creek, a large ephemeral drainage (Fig. 1). Annual precipitation ranges between 12 and $23 \mathrm{~cm}$ (5-9 inches), with a peak in May. Isolated high intensity summer thundershowers provide the majority of streamflow events. Reservoirs and wells provide most of the water for wildlife and livestock. The study sites are within a large undivided grazing allotment (North Gooseberry, 49,900 ha) administered by Bureau of Land Management. Seasonal grazing pastures were constructed on the lower Middle Fork tributary. Additionally, cattle ( 2 groups belonging to 2 permittees) grazing in the large allotment were studied in the vicinity of the lower Middle Fork tributary (group 1) and $8 \mathrm{~km}$ downstream along the Main Channel of 15-Mile Creek (group 2).

Plant communities and associated physiographic habitat occurring along 15-Mile Creek were designated for our purposes as upland, floodplain, and channel. Based on planimetered area on aerial photographs, about 2,15 , and $83 \%$ of small pastures and 5 , 25 , and $70 \%$ of the large allotment study sites were channel, floodplain, and upland habitat, respectively. The following plant species (nomenclature follows Dorn 1988) appear generally in physiognomic appearance order. The major upland species were plains 


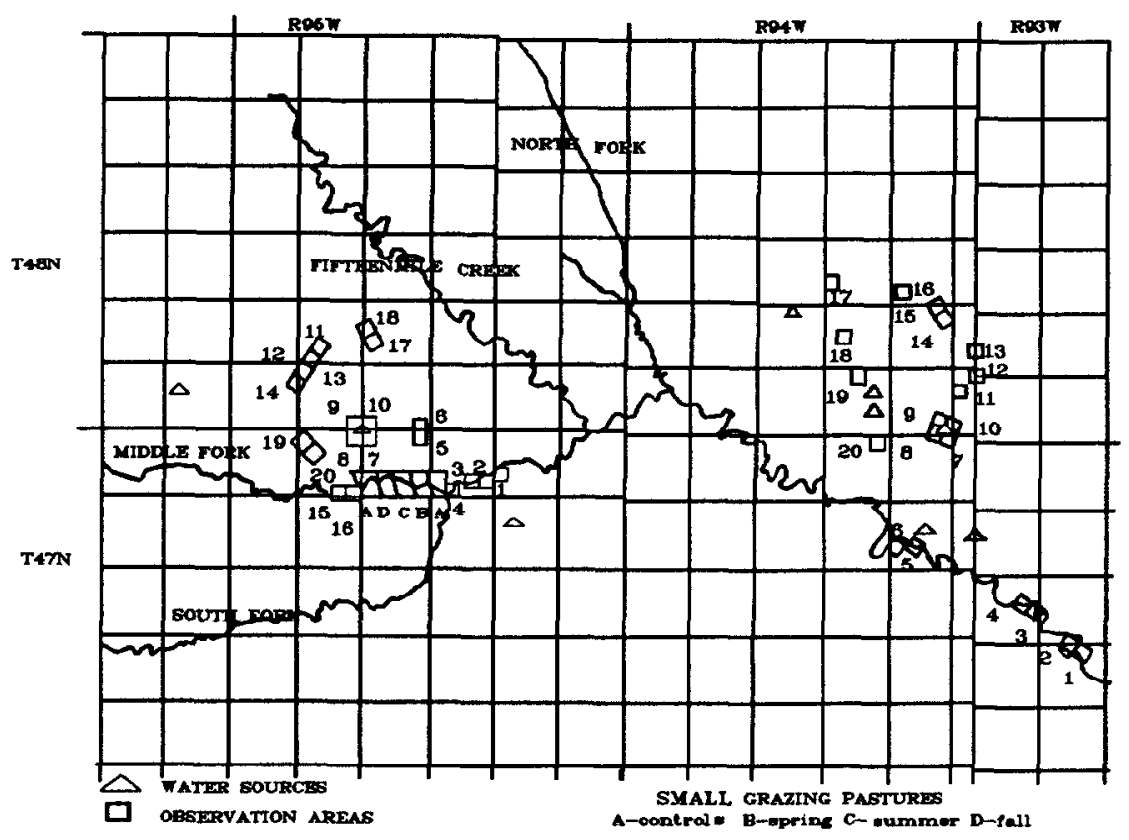

Fig. 1. Fifteen Mile Creek study area showing small seasonally grazed pastures (A-D) and large allotment observation sites (1-20) on Middle Fork (replicate 1) and on Main Channel (replicate 2). Grid lines, surveyed section lines from USGS 1:24,000 scale maps, are nominally $1.6 \mathrm{~km}$ (1 mile) apart.

pricklypear (Opuntia polyacantha Haw.), blue grama (Bouteloua gracilis (H.B.K.) Lag. ex Griffiths), needleandthread ( Stipa comata Trin. \& Rupr.), Indian ricegrass (Oryzopsis hymenoides (R. \& S.) Ricker ex Piper), and sand dropseed (Sporobolus cryptandrus (Torrey) Gray). On the floodplain, the major species were greasewood (Sarcobatus vermiculatus (Hook.) Torrey), basin big sagebrush (Artemisia tridentata Nutt. var. tridentata), cottonwood (Populus deltoides Bartr. ex Marsh.), rhizomatous wheatgrasses (Elymus spp.), Sandberg bluegrass (Poa secunda Presl.), cheatgrass brome (Bromus tectorum L.), and sixweeks grass (Vulpia octoflora (Walt.) Rydb.). In the channel the major species were inland saltgrass (Distichlis stricta (Torrey) Rydb.), Canada wildrye (Elymus canadensis L.), slim flower scurfpea (Psoralea tenuiflora Pursh), and willow (Salix exidua Nutt.) (on Main Channel only).

\section{Cattle Observations}

Observations in both a large allotment and small pasture areas enabled comparison of areas where distances to water could be great (allotment) or was small (pastures). Senft et al. (1985) and Pinchak et al. (1991) indicated characteristics of available forages should be more significant factors in habitat selection in the small pastures because water location should not be an influence. Observations of habitat selection by cattle in the large unfenced allotment provided the realism of a typically managed cattle allotment. The small pastures ( $30 \mathrm{ha}$ each) allow greater animal control and more intensive observations.

\section{Large Allotment}

Observations of cow/calf pairs in the large allotment were made in 3 seasons (mid-May to late June = spring, late June to late August $=$ summer, and late August through September $=$ fall) during 3 years in 2 areas (Fig. 1) separated by about $8 \mathrm{~km}$ : (1) along the Middle Fork and (2) north of Main Channel of 15-Mile Creek. Twenty 16-ha sites were selected to be representative of the area on each tributary and to be along routes to facilitate travel. Six of the sites, immediately adjacent to or including the stream channel had channel, floodplain, and upland habitats while 14 sites were in the uplands. Four upland sites on both Main Channel and Middle Fork were centered around a stock water reservoir approximately
$1 \mathrm{~km}$ from the channel. Other upland sites were away from reservoirs and the stream. Sites were square and marked with corner posts. Each site had an accessible observation point allowing the observer to view the site with binoculars without disturbing the cattle. Distance to water and shade varied from $0-2 \mathrm{~km}$ when water was present in all potential sources.

The Middle Fork large allotment area had 3 reservoirs. In 2 of the 3 study years, all but 1 of the reservoirs were dry by late June or early July. Of the reservoirs in the Main Channel area, 1 was a dependable source except in year 3 . Water was generally present in pools along the Main Channel but not on Middle Fork.

Each 16-ha site was systematically observed in a 2 day period biweekly to characterize animal presence and activity in 4 time frames (0600-0900 hours, 0900-1200 hours, 1200-1500 hours, 1500-1800 hours local time). The route encompassing the sites at each study area was driven twice daily in opposite directions and all observations during the 4 time frames were summarized for the respective time period. Observations recorded were instantaneous activity (grazing, including prehension/mastication and moving between feeding stations or resting, whether lying or standing), and location (in or within $10 \mathrm{~m}$ of stream channel, floodplain between channel and upland, or in upland). Additional information recorded included distance to nearest water and to nearest shade.

\section{Small Pastures}

Five exclosures of about 30 ha each were constructed across the Middle Fork and 3 were grazed seasonally ( 1 each in May-spring, July-summer, and September-fall; Fig. 1) by cattle. Each pasture was grazed only once yearly. Grazing trials were conducted in the enclosures for 3 years. Distribution in small pastures was observed only in year 2 and 3 . In each pasture, $30 \mathrm{cow} /$ calf pairs were kept for a 10-day period with water provided in troughs near the center as the stream did not usually have water. The 10-day period was established in year 1 based on the time necessary to reach a maximum utilization of $60 \%$ for the more common perennial grass species. Observations were made on the first 2 days of grazing. The observations started at dawn and continued to dusk, with observation of all 30 pairs at 15 -minute intervals. We do not feel the absence of night-time observations substantively biases our results particularly regarding comparisons between areas. Generally the 
entire pasture could be observed from a single point with the aid of binoculars. As in the large allotment, cattle activity, habitat, and distances to shade and water were recorded for each observation. An instantaneous count of cattle by activity in each habitat was made and any change in activity or habitat after the count was ignored until the following 15-minute observation. Observations were summarized by calculating percent of animals in each activity by habitats the same as with observations in the large allotment. The data summary was such that the experimental unit for analysis was a yearly pasture (season) mean $(n=8 ; 4$ time periods $\times 2$ years) for each habitat and activity.

\section{Vegetation Utilization, Quality, and Abundance}

Utilization, protein content, dry matter content, and abundance were determined during the grazing trials for plant species we expected the cattle to consume. Cattle selections of plant species and species utilization were determined by repeatedly estimating dry weight standing crop of approximately 50 individuals each of 12 plant species (grasses and greasewood listed in community descriptions) marked with nails along transects that were established in spring of year 1 (in year 2 additional utilization transects were established for greasewood). In each seasonal pasture, transects ( 2 each in the uplands and floodplains and 1 in the riparian community on the sloping channel bank) were typically $100 \mathrm{~m}$ long and were located roughly parallel to the stream channel. The above-ground biomass of marked plants was estimated prior to cattle entry and again after the cattle were removed. The difference between weight estimates was then used to calculate percentages of herbage removed (utilization). Plants in ungrazed pastures were similarly evaluated to determine if any adjustment for growth during grazing trials was necessary. Due to the short grazing period and maturity of plants, no detectable growth occurred. Weight estimates were adjusted to a dry matter basis.

Randomly selected whole plant ( $2.5 \mathrm{~cm}$-stubble height) or current growth of greasewood samples from each species (about 50 samples totaling $100 \mathrm{~g}$ of plant material) taken at beginning and end of seasonal grazing periods were oven-dried $\left(50^{\circ} \mathrm{C}\right)$ to determine percent moisture in the samples (succulence). The dried, ground samples were then used to determine \% nitrogen by the Kjeldahl method (AOAC 1975). Crude protein values reported are $\% \mathbf{N} \times 6.25$.

Standing crop biomass was determined within treatment pastures by a double sampling (harvest and estimation) technique (following Wilm et al. 1944) in July each year for major classes of herbaceous plants and cactus. The sampling was conducted on permanent transects with $0.5-\mathrm{m}^{2}$ quadrats within habitats designated for other observations. Sample size within habitats was large enough to determine the standing crop of important forage classes within $10 \%$ of the mean value $(P<0.1)$. Density of shrubs in 30 quadrats $\left(0.5 \mathrm{~m}^{2}\right)$ per pasture was determined in floodplains before grazing began.

\section{Statistical Analysis}

Due to relatively low numbers of cattle observed in the large allotment, all observations per season were pooled and the experimental unit for analysis ( $n=12 ; 4$ periods $\times 3$ years) was each of the 4 periods within days averaged over days in each of 3 years and identified as to the 3 seasonal periods and replicate, Main Channel and Middle Fork. A $t$-test $(P \leq 0.05)$ was used to compare percent of area in each habitat (planimetered from aerial photographs) with percent of cattle using habitats. Repeated measures (year, season) analysis of variance was used to test for differences between habitats and between replicate study areas.

For small pastures, the experimental unit was percent cattle in each activity in each habitat pooled over the entire seasonal grazing period for 2 years for the four 3 -hour daily time periods $(n=8)$.
Standard errors estimate variation among years and daily time periods. In the absence of replication of seasonal pastures, analyses conducted for this case study situation were $t$-test comparison of percent of cattle using a habitat with percent of habitat occurring in pastures.

Experimental unit for utilization percent, percent dry matter, and percent crude protein for each species was pasture each year categorized by forage class and habitat. Analysis of variance with repeated measures (years) was used to test for any differences between forage classes, habitats, and seasons. Scheffe's Multiple Comparisons Test (Montgomery 1984) was used to separate significantly different $(P \leq 0.05)$ means.

\section{Results and Discussion}

\section{Small Pastures}

\section{Cattle Use}

The percent of grazing, resting, and total cattle observed in channel and floodplain habitats was greater than percent occupied by these habitats in the small pastures with the exception of floodplain in fall (Table 1). In fall, total cattle and grazing cattle use on floodplain was proportional to floodplain area. Uplands were

Table 1. Percentage ( $\% \pm \mathrm{SE})^{1}$ of all cattle observed in and percent of area occupied by 3 habitats, in the seasonally grazed pastures on Middle Fork of 15-Mile Creek in year 2 and 3, 1984-1985.

\begin{tabular}{|c|c|c|c|c|}
\hline \multirow{2}{*}{ Season } & & \multicolumn{3}{|c|}{ Habitats } \\
\hline & & Channel & Floodplain & Upland \\
\hline \multicolumn{5}{|l|}{ Spring } \\
\hline $\begin{array}{l}\overline{\text { Pasture }} \\
\text { Cattle: }\end{array}$ & $\begin{array}{l}\text { total } \\
\text { grazing } \\
\text { resting }\end{array}$ & $\begin{array}{l}2.0 \\
7.2^{*} \pm 0.8 \\
10.6^{*} \pm 0.9 \\
11.1^{*} \pm 2.0\end{array}$ & $\begin{array}{l}12.6 \\
40.3^{*} \pm 3.0 \\
27.3^{*} \pm 1.8 \\
39.0^{*} \pm 6.0\end{array}$ & $\begin{array}{l}85.4 \\
52.5^{*} \pm 3.5 \\
62.2^{*} \pm 2.7 \\
49.9^{*} \pm 5.1\end{array}$ \\
\hline \multicolumn{5}{|l|}{ Summer } \\
\hline $\begin{array}{l}\text { Pasture } \\
\text { Cattle: }\end{array}$ & $\begin{array}{l}\text { total } \\
\text { grazing } \\
\text { resting }\end{array}$ & $\begin{array}{r}1.3 \\
14.1^{*} \pm 5.1 \\
6.2^{*} \pm 1.7 \\
13.8^{*} \pm 4.7\end{array}$ & $\begin{array}{l}12.6 \\
35.5^{*} \pm 5.0 \\
36.0^{*} \pm 3.5 \\
50.1^{*} \pm 5.2\end{array}$ & $\begin{array}{l}86.1 \\
46.4^{*} \pm 9.8 \\
57.9^{*} \pm 5.1 \\
35.1^{*} \pm 8.8\end{array}$ \\
\hline \multicolumn{5}{|l|}{ Fall } \\
\hline $\begin{array}{l}\text { Pasture } \\
\text { Cattle: }\end{array}$ & $\begin{array}{l}\text { total } \\
\text { grazing } \\
\text { resting }\end{array}$ & $\begin{array}{l}2.3 \\
17.9^{*} \pm 4.0 \\
16.5^{*} \pm 2.7 \\
7.6^{*} \pm 1.4\end{array}$ & $\begin{array}{l}19.3 \\
26.2 \pm 2.7 \\
24.8 \pm 3.2 \\
51.5^{*} \pm 5.1\end{array}$ & $\begin{array}{l}78.4 \\
55.9^{*} \pm 6.2 \\
58.8^{*} \pm 5.7 \\
41.0^{*} \pm 6.2\end{array}$ \\
\hline
\end{tabular}

All Seasons

\begin{tabular}{lllll}
\hline Pasture & & 1.9 & 14.9 & 83.3 \\
Cattle: & total & $13.1^{*} \pm 2.3$ & $34.0^{*} \pm 2.3$ & $51.6^{*} \pm 4.0$ \\
& grazing & $11.1^{*} \pm 1.4$ & $29.4^{*} \pm 1.9$ & $59.6^{*} \pm 2.6$ \\
& resting & $10.8^{*} \pm 1.8$ & $46.9^{*} \pm 3.2$ & $42.0^{*} \pm 4.0$
\end{tabular}

'SE = standard error of mean; means are \% of cattle observed in a habitat in an activity or of total thus grazing and resting will not sum to total.

* The percentage of cattle observed was different from the expected random distribution in a given habitat within season at $p \leq .05$ with 7 d.f. season, 21 d.f. all seasons.

always used in lesser proportion for grazing, resting, and total cattle than indicated by area of habitats (Table 1). Floodplain habitats had the greatest percent of resting cattle while uplands had the greatest percent of grazing cattle, although percent cattle was not as great as the percent area of the habitat in the area. Changes in selection of habitats were probably related to seasonal pasture differences such as biomass availability.

Water, shade, and topography influence the distribution of grazing animals (Gonzalez 1964, Mueggler 1965, Cook 1966, Arnold and Dudzinski 1978). In the seasonal pastures maximum distance to water and shade was only $700 \mathrm{~m}$ and $400 \mathrm{~m}$, respectively. Shade 
and water occurred only in the preferred channel and floodplain habitats and seemed related to the higher incidence of resting behavior (Table 1) in those habitats.

\section{Forage Quantity}

We hypothesized that since water and shade should not be limiting and topographic variation was minor, forage abundance and quality would be closely related to cattle selection of habitats for grazing (Dudzinski et al. 1978, Pinchak et al. 1991, Senft et al. 1985). Channels produced more herbaceous vegetation (Table 2) than other habitats while floodplain and upland had similar, lower

Table 2. Herbaceous vegetation standing crop $\left(\mathrm{g} / \mathrm{m}^{2} \pm \mathrm{SE}\right)^{1}$ in the $3 \mathrm{hab}-$ itats of seasonal pastures on Middle Fork, 15-Mile Creek in years 1-4, 1983-1986.

\begin{tabular}{|c|c|c|c|}
\hline & \multicolumn{3}{|c|}{ Habitat } \\
\hline & Channel & Floodplain & Upland \\
\hline Pasture & \multicolumn{3}{|c|}{$\ldots \ldots \mathrm{g} \mathrm{m}^{-1} \pm \mathrm{SE} \ldots \ldots$} \\
\hline $\begin{array}{l}\text { Spring } \\
\text { Summer } \\
\text { Fall } \\
\text { Mean }\end{array}$ & $\begin{array}{l}25 \pm 6 \\
41 \pm 11 \\
47 \pm 16 \\
38\end{array}$ & $\begin{array}{l}8 \pm 1 \\
18 \pm 3 \\
20 \pm 5 \\
15\end{array}$ & $\begin{array}{l}21 \pm 4 \\
26 \pm 6 \\
15 \pm 3 \\
21\end{array}$ \\
\hline
\end{tabular}

ISE = standard error of mean

herbage abundance. However, the unmeasured amount of current annual growth of greasewood likely provided increased forage for cattle in the floodplain above amounts in uplands. Density of greasewood in terraces of seasonal pastures was $0.8,0.8$, and 4.2 plants $\mathrm{m}^{2}$ in fall, summer, and spring pastures, respectively. Greasewood did not occur in other habitats.

\section{Forage Protein}

Annual grasses, most abundant in the floodplain and minor elsewhere, had the least protein; and greasewood, particularly new growth, had the highest amounts (Table 3). Perennial grasses had

Table 3. Forage crude protein ( $\% \pm \mathrm{SE})^{1}$ in 3 habitats of seasonally grazed pastures on the Middle Fork of 15 Mile Creek in years 2-3, 1984-1985.

\begin{tabular}{|c|c|c|c|c|}
\hline \multirow{2}{*}{$\begin{array}{l}\text { Habitat and } \\
\text { forage class }\end{array}$} & \multicolumn{4}{|c|}{ Seasons } \\
\hline & Spring & Summer & Fall & All seasons \\
\hline Channel & \multicolumn{4}{|c|}{ - $\%$ 土 SE } \\
\hline $\begin{array}{l}\text { Perennial } \\
\text { Grass }\end{array}$ & $12.9 \pm 2$ & $6.8 \pm .3$ & $5.4 \pm .29$ & $8.5 \pm .3 b$ \\
\hline \multicolumn{5}{|l|}{ Floodplain } \\
\hline Perennial & $14 \pm .6$ & $5.3 \pm .4$ & $4.11 \pm .2$ & $8.4 \pm .5 b$ \\
\hline $\begin{array}{l}\text { Annual } \\
\text { Grass }\end{array}$ & $9.5 \pm .4$ & $4.5 \pm .3$ & $3.3 \pm .2$ & $6.1 \pm .3 \mathrm{a}$ \\
\hline Greasewood & $21.3 \pm .8$ & $12.6 \pm .8$ & $13.9 \pm .4$ & $16.1 \pm .6 \mathrm{~d}$ \\
\hline Upland & & & & \\
\hline $\begin{array}{l}\text { Perennial } \\
\text { Grass }\end{array}$ & $16.9 \pm .3$ & $6.8 \pm .2$ & $5.5 \pm .2$ & $9.7 \pm .4 c$ \\
\hline All Habitats ${ }^{2}$ & $14.8 \pm .3 a$ & $6.8 \pm .2 b$ & $6.0 \pm .2 \mathrm{c}$ & \\
\hline
\end{tabular}

ISE = standard error of mean

2Means in bottom row and last column followed by the same letter were not significantly different, $p \leq 0.05$.

intermediate protein levels. Crude protein of perennial grasses was the same in channel and terrace while slightly greater in uplands.

\section{Forage Succulence}

Dry matter content of forages differed (Table 4). Perennial grasses in channel and upland were lower in dry matter than in terrace. Annual grasses in terraces had highest dry matter while
Table 4. Forage dry matter $(\% \pm \mathrm{SE})^{1}$ in seasonally grazed pastures on the Middle Fork of 15 Mile Creek in years 2 and 3, 1984-1985.

\begin{tabular}{|c|c|c|c|c|}
\hline \multirow{2}{*}{$\begin{array}{l}\text { Habitat and } \\
\text { forage class }\end{array}$} & \multicolumn{4}{|c|}{ Seasons } \\
\hline & Spring & Summer & Fall & $\mathrm{All}^{2}$ \\
\hline $\begin{array}{l}\text { Channel } \\
\text { Perennial } \\
\text { Grass }\end{array}$ & $29.8 \pm 2.0$ & $50.9 \pm 2.7$ & $72.6 \pm .9$ & $51.1 \pm 3.8 \mathrm{~b}$ \\
\hline $\begin{array}{l}\text { Floodplain } \\
\text { Perennial } \\
\text { Grass } \\
\text { Annual } \\
\text { Grass } \\
\text { Greasewood }\end{array}$ & $\begin{array}{l}40.1 \pm 2.0 \\
21.7 \pm 1.2\end{array}$ & $\begin{array}{l}78.0 \pm 7.0 \\
33.4 \pm 2.5\end{array}$ & $\begin{array}{l}97.0 \pm .5 \\
49.6 \pm 2.0\end{array}$ & $\begin{array}{l}71.7 \pm 5.4 \mathrm{c} \\
34.9 \pm 2.6 \mathrm{a}\end{array}$ \\
\hline $\begin{array}{l}\text { Upland } \\
\text { Perennial } \\
\text { Grass }\end{array}$ & $44.5 \pm 2.8$ & $58.6 \pm 2.0$ & $78.2 \pm 2.3$ & $60.43 \pm 2.4 b$ \\
\hline All Habitats 2 & $35.8 \pm 1.7 \mathrm{a}$ & $58.9 \pm 2.6 b$ & $77.1 \pm 2.3 \mathrm{c}$ & \\
\hline
\end{tabular}

1SE = standard error of mean

${ }^{2}$ Means for seasons (All Habitat row) or for forage class (All Scasons column) followed by the same letter were not significantly different, $p \leq .05$.

greasewood with least dry matter was the most succulent forage (Table 4).

\section{Forage Characteristic Effects on Habitat Selection}

Forages in the channel had greatest biomass, were intermediate in crude protein, and high in succulence compared to grasses in other habitats. Biomass available, crude protein, and succulence are generally known to be positively associated with habitat selection by cattle (Pinchak et al. 1991, Langlands and Bennett 1973, Senft et al. 1985, Roath and Krueger 1982, Arnold and Dudzinski 1978). Channels were preferentially selected, suggesting the influence of forage characteristics on selection. Greasewood quality appears to provide the only reason for grazing cattle to show preference for the floodplain areas because quantity and quality of other forages were either similar or inferior to those of uplands. Greasewood had the highest quality values of any forage and was relatively abundant. Livestock normally select forages high in nitrogen (Hardison et al. 1954, Cook et al. 1956, Wier and Torrell 1959, Cowlishaw and Alder 1960) and succulence (Arnold 1960, Reppert 1960).

Upland areas had relatively low forage quantity, mainly blue grama, a species of low growth habitat. Additionally, all species were of relatively low succulence even though crude protein levels were comparable to or higher than forages in other habitats.

Protein content of all forage classes dropped (Table 3 ) and dry matter (Table 4) increased dramatically from spring to summer and, to a lesser extent, into fall. Galt et al. (1969), Bedell (1971), Wallace et al. (1972), Philip (1966) report similar findings. These changes were similar in all habitats and did not change the general preferences by cattle. Minor changes were evident, particularly the reduced selection for floodplains in fall (Table 1), possibly due to increased maturity and woodiness of greasewood.

\section{Effects of Habitat Selection on Utilization of Forages}

Even though grazing cattle were found in channel and floodplain habitats more commonly than area of habitats would suggest, forage utilization averages for habitats (Table 5) did not correspondingly increase. Utilization of channel and upland forages (perennial grasses, Table 5) was similar. In contrast, the apparently preferred floodplain habitat contained the forage class with lowest use of all classes (annual grass) as well as the class with highest use (greasewood). The higher use of greasewood appears to be the only case where preference for the habitat resulted in increased use of a 
Table 5. Utilization (\% $\pm \mathrm{SE})^{1}$ of annual forage growth in the 3 habitats in seasonally grazed pastures on the Middle Fork of 15-Mile Creek in years 2 and 3, 1984-1985.

\begin{tabular}{|c|c|c|c|c|}
\hline \multirow{2}{*}{$\begin{array}{l}\text { Habitat and } \\
\text { forage class }\end{array}$} & \multicolumn{4}{|c|}{ Seasons } \\
\hline & Spring & Summer & Fall & All seasons \\
\hline $\begin{array}{c}\text { Channel } \\
\text { Perennial } \\
\text { Grass }\end{array}$ & $38.0 \pm 1.9$ & $40.6 \pm 1.7$ & $\begin{array}{ll}48 & 1.7\end{array}$ & $42.7 \pm 1.0 b$ \\
\hline $\begin{array}{l}\text { Floodplain } \\
\text { Perennial } \\
\text { Grass }\end{array}$ & $32.0 \pm 2.3$ & $36.6 \pm 1.9$ & $51.0 \pm 2.0$ & $40.5 \pm 1.2 b$ \\
\hline $\begin{array}{l}\text { Annual Grass } \\
\text { Greasewood }\end{array}$ & $\begin{array}{l}30.2 \pm 2.4 \\
43.3 \pm 3.1\end{array}$ & $\begin{array}{l}20.7 \pm 1.9 \\
57.4 \pm 3.5\end{array}$ & $\begin{array}{l}18.9 \pm 2.0 \\
55.6 \pm 3.0\end{array}$ & $\begin{array}{l}23.2 \pm 1.2 \mathrm{a} \\
52.2 \pm 1.9 \mathrm{c}\end{array}$ \\
\hline $\begin{array}{l}\text { Upland } \\
\text { Perennial } \\
\text { Grass }\end{array}$ & $31.5 \pm 1.5$ & $31.3 \pm 30.0$ & $55.8 \pm 1.3$ & $40.0 \pm 0.8 b$ \\
\hline $\mathrm{All}^{2}$ & $33.6 \pm 0.9 \mathrm{a}$ & $33.6 \pm 0.8 \mathrm{a}$ & $47.5 \pm 0.9 b$ & \\
\hline
\end{tabular}

ISE = standard error of mean

2Means for seasons (All Habitat row) or for forage class (All Seasons forage class column) followed by the same letter were not significantly different, $p \leq .05$.

\section{forage class.}

Utilization varied among species in this study (data in Smith et al. 1989), with the high quality new growth of greasewood receiving highest use, up to $77 \%$ in summer. Bunchgrasses or grasses with upright growth habits, including Canada wildrye, wheatgrasses, Indian ricegrass, and needleandthread, received moderate use (about 50\%). Lowest use, 29-34\%, occurred on low growing and annual species, including inland saltgrass, Sandberg bluegrass, cheatgrass brome, sixweeks grass, blue grama, and sand dropseed.

In general, utilization was similar in spring and summer and increased in fall (Table 5). Higher greasewood utilization levels, with respect to other species within seasons and across seasons, illustrated the effect high forage quality can have on increasing selection by grazers. Less variation occurred in utilization in spring, when forage quality was similar, than in other seasons when more variation in quality of species occurred as shown by Arnold et al. (1966).

\section{Free Ranging Cattle in the Large Allotment}

In general, habitat preferences (Table 6) were similar to those in the seasonal pastures (Table 1), with greater proportional use of channel and floodplain in the large allotment than area present and less use than area present in uplands. We regard these findings as a verification of the applicability of the small pasture studies to larger areas of similar vegetation and landforms and additionally as a means of reemphasizing the importance of water developments to grazing management. Water location appeared to be influential in cattle selection of habitats in the large allotment. In the large allotment, a slightly greater proportion of cattle selected channel and floodplain habitats near water, and fewer cattle used uplands than in the small seasonal pastures (Tables 1 and 6).

Variation among seasons in habitat selection in the large allotment was evident (significant habitat by season interaction) (Table 6). The use of the channel where water was present increased in summer while use declined in the floodplain. Similar changes did not occur in seasonal pastures (Table 1), probably because the ephemeral channels of seasonal pastures did not contain water. No water was available at upland reservoirs in Year 3; thus, cattle reduced selection of uplands in year 3 to $14 \%$ compared to 44 and $49 \%$ cattle in uplands in year 1 and 2 respectively.

We concluded that when adequate livestock water was present, grazing cattle would be more likely to select areas of higher quality
Table 6. Habitat use by free-ranging cattle $(\% \pm \mathrm{SE})^{1}$ in all activities and percent of area occupied by 3 habitats of the Main Channel and Middle Fork sites of 15 Mile Creek in years 1-3, 1983-1985.

\begin{tabular}{|c|c|c|c|}
\hline \multirow{2}{*}{$\begin{array}{l}\text { Study Locations } \\
\text { and Seasons }\end{array}$} & \multicolumn{3}{|c|}{ Habitats } \\
\hline & Channel & Floodplain & Upland \\
\hline $\begin{array}{l}\text { Main Channel } \\
\text { Area Use } \\
\text { Spring } \\
\text { Summer } \\
\text { Fall }\end{array}$ & $\begin{array}{l}3.9 \\
21.6^{*} \pm 3.1 \\
32.5^{*} \pm 6.5 \\
15.8^{*} \pm 5.0\end{array}$ & $\begin{array}{l}--\% \pm S E- \\
26.1 \\
40.4^{*} \pm 4.7 \\
29.5^{*} \pm 5.8 \\
52.9^{*} \pm 6.0\end{array}$ & $\begin{array}{l}70.0 \\
37.5^{*} \pm 6.7 \\
38.1^{*} \pm 8.7 \\
31.2^{*} \pm 8.3\end{array}$ \\
\hline All Seasons & $24.0^{*} \pm 3.3 \mathrm{a}^{2}$ & $40.2^{*} \pm 4.1 b$ & $35.7^{*} \pm 5.0 \mathrm{ab}$ \\
\hline $\begin{array}{l}\text { Middle Fork } \\
\text { Area Use } \\
\text { Spring } \\
\text { Summer } \\
\text { Fall }\end{array}$ & $\begin{array}{l}5.0 \\
21.4^{*} \pm 3.2 \\
32.9^{*} \pm 7.4 \\
17.3 \pm 5.3\end{array}$ & $\begin{array}{l}25.0 \\
40.9^{*} \pm 4.7 \\
29.7 \pm 6.4 \\
50.9^{*} \pm 9.2\end{array}$ & $\begin{array}{l}70.0 \\
37.6^{*} \pm 6.6 \\
37.5^{*} \pm 8.6 \\
31.8^{*} \pm 11.3\end{array}$ \\
\hline All Seasons & $23.3^{*} \pm 3.1 \mathrm{a}$ & $40.9^{*} \pm 3.5 b$ & $35.6^{*} \pm 4.5 b$ \\
\hline $\begin{array}{l}\text { Combined Areas } \\
\text { Area Use } \\
\text { Spring } \\
\text { Summer } \\
\text { Fall }\end{array}$ & $\begin{array}{l}4.5 \\
21.5^{*} \pm 2.2 \\
32.7^{*} \pm 4.8 \\
16.5^{*} \pm 3.6\end{array}$ & $\begin{array}{l}25.5 \\
40.7^{*} \pm 3.2 \\
29.6 \pm 4.2 \\
52.0^{*} \pm 5.3\end{array}$ & $\begin{array}{l}70.0 \\
37.5^{*} \pm 4.6 \\
37.8^{*} \pm 6.0 \\
31.5^{*} \pm 6.8\end{array}$ \\
\hline All Seasons & $23.7^{*} \pm 2.2 \mathrm{a}$ & $40.6^{*} \pm 2.7 b$ & $35.7^{*} \pm 3.3 b$ \\
\hline
\end{tabular}

ISE = standard error of mean

${ }^{2}$ Means for habitats (All Seasons rows) followed by the same letter were not significantly different, $p \leq 05 *$ The percentage of cattle observed was different from the expected random distribution in a given habitat and season, $p \leq .05,11$ d.f., for Main and $M F$ and 22 d.f. combined, for seasons within habitats.

and quantity of forages. However in our case, increased selection did not result in increased utilization compared to other areas. Limited water, as in the large allotment, would likely increase utilization closer to water. Due to the importance of the channel area in maintaining habitat diversity and trapping sediment (Schumm and Meyer 1979), grazing management should emphasize maintenance of channel vegetation. No particular season of grazing seemed to result in more detrimental grazing utilization of channels when water was not limited. Based on our studies, vegetation in or near channels can be best protected by developing water points in adjacent uplands.

\section{Literature Cited}

Ames, C.R. 1978. Wildlife conflicts in riparian management: Grazing. p. 39-51. In: Importance, preservation and management of riparian habitat. USDA Forest Serv. Gen. Tech. Rep. RM-43.

AOAC. 1975. Official methods of analysis. 12th Edition. Assoc. Official Anal. Chem. Washington, D.C.

Arnold, G.W. 1960. Selective grazing by sheep of two forages species at different stages of growth. Aust. J. Agr. Res. 11:1026-1033.

Arnold, G.W., J. Ball, W.R. McManus, and I.G. Bush. 1966. Studies on the diet of the grazing animal. 1. Seasonal changes in the diet of sheep grazing on pastures of different availability and composition. Aust. $\mathbf{J}$. Agr. Res. 17:543-556.

Arnold, G.W., and M.L. Dudzinski. 1978. Ethology of free-ranging domestic animals. Elsevier Scientific Publ. Co. Amsterdam.

Bedell, T.E. 1971. Nutritive value of forage and diets of sheep and cattle from Oregon subclover-grass mixtures. J. Range Manage. 24:125-133.

Bryan, K. 1925. Date of channel trenching (arroyo cutting) in the arid Southwest. Science 12:328-334.

Cook, C.W., L.A. Stoddart, and L.E. Harris. 1956. Comparative nutritive value and palatability of some introduced and native forage plants for spring and summer grazing. Utah Agr. Exp. Sta. Bull. 385.

Cook, C.W. 1966. Factors affecting utilization of mountain slopes by cattle. J. Range Manage. 19:200-204.

Cowlishaw, S.J., and F.E. Alder. 1960. The grazing preferences of cattle and sheep. J. Agr. Sci., Camb. 54:257-265.

Dorn, R.D. 1988. Vascular plants of Wyoming. Mountain West Publishing. Cheyenne, Wyo, 
Dudzinski, M.L., H.J. Schu, D.G. Wilcox, H.G. Gardner, and J.G. Morissey. 1978. Statistical and probablistic estimations of forage conditions from grazing behavior of Merino sheep in a semi-arid environment. $J$. Appl. Anim. Ethol. 4:357-368.

Galt, H.D., B. Theurer, J.H. Ehrenhreich, W.H. Hale, and S.C. Martin. 1969. Botanical composition of diet of steers grazing a desert grassland range. J. Range Manage. 22:14-19.

Gonzalez, M.H. 1964. Patterns of livestock behavior and forage utilization as influenced by environmental factors on summer mountain range. $\mathrm{PhD}$ thesis. Utah State Univ. Logan.

Hardison, W.A., J.T. Reid, C.M. Martin, and P.G. Woolfolk. 1954. Degree of herbage selection by grazing cattle. J. Dairy Sci. 37:89-101.

Kauffman, J.B., and W.C. Krueger. 1984. Livestock impacts on riparian ecosystems and streamside management implications...A review. J. Range Manage. 37:430-437.

Langlands, J.P., and I.L. Bennett. 1973. Stocking intensity and pastoral production. III. Wool production, fleece characteristics and the utilization of nutrients for maintenance and wool growth by Merino sheep grazed at different stocking rates. J. Agr. Sci., Camb. 81:211-218.

Montgomery, D.C. 1984. Design and analysis of experiments. 2nd ed. John Wiley and Sons, N.Y.

Mueggler, W.F. 1965. Cattle distribution on steep slopes. J. Range Manage. 18:255-257.

Philip, J.R. 1966. Plant-water relations: some physiological aspects. Annu. Rev. Plant Physiology 17:245-268.

Pinchak, W.E., M.A. Smith, R.H. Hart, and J.W. Waggoner Jr. 1991. Beef cattle grazing distribution patterns on foothill range. J. Range Manage. 44:267-275
Reppert, J.N. 1960. Forage preference and grazing habitats of cattle at the Eastern Colorado Range Station. J. Range Manage. 13:58-64.

Roath, L.R., and W.C. Krueger. 1982. Cattle grazing influence in a mountain riparian zone. J. Range Manage. 35:100-104.

Schumm, S.A., and D.A. Meyer. 1979. Morphology of alluvial rivers of the Great Plains. p. 9-14. In: Proc. 31st Annu. Meeting Great Plains Agr. Counc. GPAC Pub. 91.

Senft, R.L., R.L. Rittenhouse, and R.G. Woodmansee. 1985. Factors influencing patterns of cattle grazing behavior on shortgrass steppe. J. Range Manage. 38:82-87.

Smith, M.A., Q.D. Skinner, J.D. Rodgers, J.L. Dodd, and R.E. Siekert. 1989. Channel and riparian zone responses along 15-Mile Creek, Bighorn Basin, Wyoming. Final Rep. to Wyoming Dep. Environmental Quality. Range Manage. Dep. Univ. Wyoming, Laramic 82071.

Wallace, J.D., J.C. Free, and A.H. Denham. 1972. Seasonal changes in herbage and cattle diets on sand hill grassland. J. Range Manage. 25:100-104.

Weir, W.C., and D.T. Torrell. 1959. Selective grazing by sheep as shown by a comparison of the chemical composition of range and pasture forage obtained by hand clipping and that collected by esophageal fistulated sheep. J. Anim. Sci. 18:641-649.

Wilm, H.G., D.F. Costello, and G.E. Klipple. 1944. Estimating forage yield by the double sampling method. J. Amer. Soc. Agron. 36:323-325. 